\title{
Advancement of the Engineering Management Body of Knowledge
}

\begin{abstract}
Trade around the world has become globally interconnected. Engineers play an integral role in designing products, managing supply chains, providing services, and increasing the quality of life for people and promoting sustainable development around the globe. Engineering managers make decisions every day that will have profound impacts on international suppliers, customers, partners, consumers, and the environment.

Traditional education for engineering students focuses on the technical aspects and scientific principles. Education in some countries may focus exclusively on mathematics, science, and engineering topics. The North American model incorporates a general education component into the undergraduate program of study to give students a broad appreciation of ideas ranging from art to literature to the social sciences.

This paper will investigate how undergraduate engineering management programs educate their students to be able to work in international settings or in the global workplace. This initial study will concentrate on the engineering management programs that are accredited by ABET, an international organization that accredits technical programs in higher education. ABET has accredited over 3,400 programs in applied science, computing, engineering, and engineering technology in 28 countries. This study will access publicly available information to determine the breadth and depth of education related to helping prepare engineering management students to work in a global marketplace. These data will be collected from the
\end{abstract}

Manuscript received October 20, 2014; accepted January 10, 2015

David A. Wyrick (ه)

American Society for Engineering Management, Huntsville, Alabama, 25805, USA

Email: dawyrick@yahoo.com

Paul Kauffmann

College of Engineering and Technology, East Carolina University Greenville, North Carolina, 27858-4353, USA

Libby Schott, John V. Farr

Department of Systems Engineering, United States Military Academy,

West Point, New York State, New York, 10996, USA programs accredited by ABET using the "Engineering Management" program criteria, due to the public availability of this information. Initial findings will be presented, and may serve to identify opportunities for cooperation and further work.

Keywords: engineers, engineering management, knowledge, education, programs

\section{Introduction}

Engineering education prepares students to become practicing engineers. In many cases, this education takes place in universities. In the United States and many other countries, the curriculum typically takes the form of a four-year degree. These degrees typically have a strong foundation in mathematics and basic sciences, upon which an engineering specialization is built. In the US, programs also include a general education that includes social sciences, the humanities, arts, and interpersonal and social courses, all of which are intended to produce "well-rounded" engineers who appreciate and consider non-technical factors into their technical recommendations and decisions. Engineering programs that are not based on the American model, the five-year French diplome des Grandes Ecoles, for example, has in the past concentrated nearly all courses in mathematics, sciences, and engineering, although these programs are beginning to provide other types of courses to help "round out" their engineers.

This approach has been very successful in the past for the traditional disciplines, such as mechanical, electrical, and civil engineering. In the past, most engineers worked in their own countries and chiefly on domestic projects. Work has become much more global and international in the recent past, and many mundane products now consist of materials and components sourced along a global supply chain, with customers located in many countries.

Concurrent with the rise in increasing globalization and internationalization is the growth and recognition of engineering management programs. In the United States, 
engineering management programs are largely designed like other engineering programs. However, EM graduates move into technical sales, quality, purchasing, project management, and other management areas faster than graduates from other engineering programs, and may begin working in positions that require them to interface with international colleagues earlier in their career.

This raises the question of how engineering management programs prepare their students to be able to work in global settings and with international colleagues.

To investigate this question, this study will evaluate publicly available material for undergraduate engineering management programs that are accredited by the Engineering Accreditation Commission of ABET (ABET-EAC). Results of this material will be reported and discussed. The information, or lack of information, will be the basis of discussion. Further work and conclusions will conclude the paper.

\section{ABET-accredited undergraduate engineering management programs}

This section will discuss ABET and its approach to assuring quality in technical education, especially regarding engineering management programs. The engineering management programs accredited by ABET will be presented. For these programs, how they approach the global skills and internationalization aspects will be summarized, based on publicly available information.

\subsection{ABET and program accreditation}

ABET, Inc., is a leading agency for the accreditation of educational programs in engineering, computing, engineering technology, and applied sciences. ABET accredits programs, not departments or colleges. Four commissions accredit programs in the areas of engineering, computing, engineering technology, and applied sciences. ABET was established in 1932 as the "Engineers' Council for Professional Development" to accredit programs in the United States. The name was changed to the Accreditation Board for Engineering Technology in 1980 and started using its simplified ABET name in 2005. ABET began international activities in 1979 (ABET, Inc., 2015a), and has accredited over 3, 400 programs in applied science, computing, engineering, and engineering technology in 28 countries (ABET, Inc., 2015b).

ABET is an organization whose members consist of professional engineering societies rather than individuals. While ABET collectively sets the general criteria by which programs are accredited, the appropriate member organizations establish the program specific criteria (IEEE sets the program criteria for electrical engineering programs, for example) (ABET, Inc., 2015c).
The general criterion for accrediting engineering programs is fairly detailed. With regards to curriculum, ABET requires at least 32 semester credits (or $25 \%$ of the total program credits, whichever is lower) to be in mathematics and basic sciences, with the minimum level of mathematics established by the appropriate professional society(ies). ABET requires at least 48 semester credits (or $37.5 \%$ of the total program credits, whichever is lower) to be in engineering topics. The remainder of the program is for general education appropriate to the institution or for other courses and electives specified by the program (ABET, Inc., 2015d).

For engineering management programs, the programspecific criteria set and used by ABET deal with curriculum and with faculty. "The curriculum must prepare graduates to understand the engineering relationships between the management tasks of planning, organization, leadership, control, and the human element in production, research, and service organizations; to understand and deal with the stochastic nature of management systems. The curriculum must also prepare graduates to integrate management systems into a series of different technological environments." "The major professional competence of the faculty must be in engineering, and the faculty should be experienced in the management of engineering and/or technical activities" (ABET, Inc., 2015d).

A deeper evaluation of ABET criteria and engineering management programs is located in a paper to be delivered at the 2015 Annual Conference and Exposition of the American Society for Engineering Education (Kauffmann, Farr, Schott, \& Wyrick, 2015).

\subsection{ABET-accredited engineering management programs}

The 16 ABET-accredited engineering management programs that were accredited after the 2013 fall visit accreditation cycle are tabulated in Table 1. Eleven of these are located in the United States and five are international. This information is available from ABET using its online program search feature. This search was limited to bachelors' level programs accredited by the Engineering Accreditation Commission. The exhibit indicates the university, its country, and year of initial accreditation (ABET, Inc., 2015e).

\section{Global skills and internationalization aspects}

To determine how programs introduce topics that relate to globalization and the requirements of an international workplace, the websites of the 16 ABET-accredited programs were reviewed. This review attempted to identify particular courses that concentrate on these topics, relevant study abroad experiences, and other opportunities for 
Table 1

ABET-Accredited Engineering Management Programs

\begin{tabular}{|c|c|c|}
\hline University & Country & Initial \\
\hline Arab Academy for Science and Technology and Maritime Transport & Egypt & 2009 \\
\hline University of Arizona & United States & 2003 \\
\hline Clarkson University & United States & 2009 \\
\hline University of Connecticut & United States & 2007 \\
\hline Istanbul Technical University & Turkey & 2009 \\
\hline Kuwait University & Kuwait & 2006 \\
\hline Missouri University of Science and Technology & United States & 1979 \\
\hline North Dakota State University & United States & 1971 \\
\hline Oklahoma State University & United States & 1936 \\
\hline University of the Pacific & United States & 2003 \\
\hline Rensselaer Polytechnic Institute & United States & 1978 \\
\hline Universidad Autonoma de San Luis Potosi & Mexico & 2012 \\
\hline University of Sharjah & United Arab Emirates & 2010 \\
\hline South Dakota School of Mines and Technology & United States & 1991 \\
\hline Stevens Institute of Technology & United States & 1990 \\
\hline United States Military Academy & United States & 1995 \\
\hline
\end{tabular}

students to be engaged in international and global aspects. Whenever possible, the particular program websites or university catalogs were reviewed; difficulties encountered included broken links and language other than English.

The primary websites for each of the programs is listed in Table 2. This exhibit also gives the program name as it is accredited by ABETS.

Review of the program websites indicates that no program has a dedicated course that deals explicitly with the impact of globalization and how to work effectively in an international setting. At least one program identifies an elective course in global perspectives as part of its general education program (North Dakota State University).

Several programs have courses in supply chain management as either a required course or as an elective (AASTMT, Clarkson, Kuwait, and Stevens). It is not clear if these courses deal with the cultural aspects of effective supply chain management or if they concentrate on the mathematical modeling and simulation of supply chains. University of Sharjah includes a section on the global economy as part of its senior level strategic marketing course.

Three universities advertise an integrated study abroad experience as part of its engineering management program. The University of Connecticut has a one-semester visit to the University of Lund in Sweden. Stevens Institute of Technology offers a two-week faculty-led course to the University of Naples in Italy. Clarkson University is the most progressive as it will require all of its BSEM students to have an international experience beginning in 2017.
It is possible that programs introduce the expectations of working in a global marketplace in its curriculum as parts of individual courses. Based on the review of this material that is publicly available, it is not possible to clearly identify that, however.

University of the Pacific offers seven tracks of specialization. One of these tracks is "International Engineering Management," which is targeted for students who are interested in global careers.

In related work by the authors for the American Society for Engineering Education (ABET, Inc., 2015e), the relationship of the managerial topics relative to the requirements for math and science, engineering topics, and general education was explored for a subset of these schools.

\section{Discussion of findings}

There are two areas in which the results can be classified. First is the accreditation of engineering management programs by ABET. Second is how these programs prepare their students to work in a global marketplace.

The number of programs accredited by ABET is increasing. Since 2000 , the number of programs has more than doubled from seven to 16 . Of the newest nine programs, five are located outside the United States. It is likely that this trend of internationalization will continue. Most American programs in engineering management are offered at the master's level, and the typical approach is 


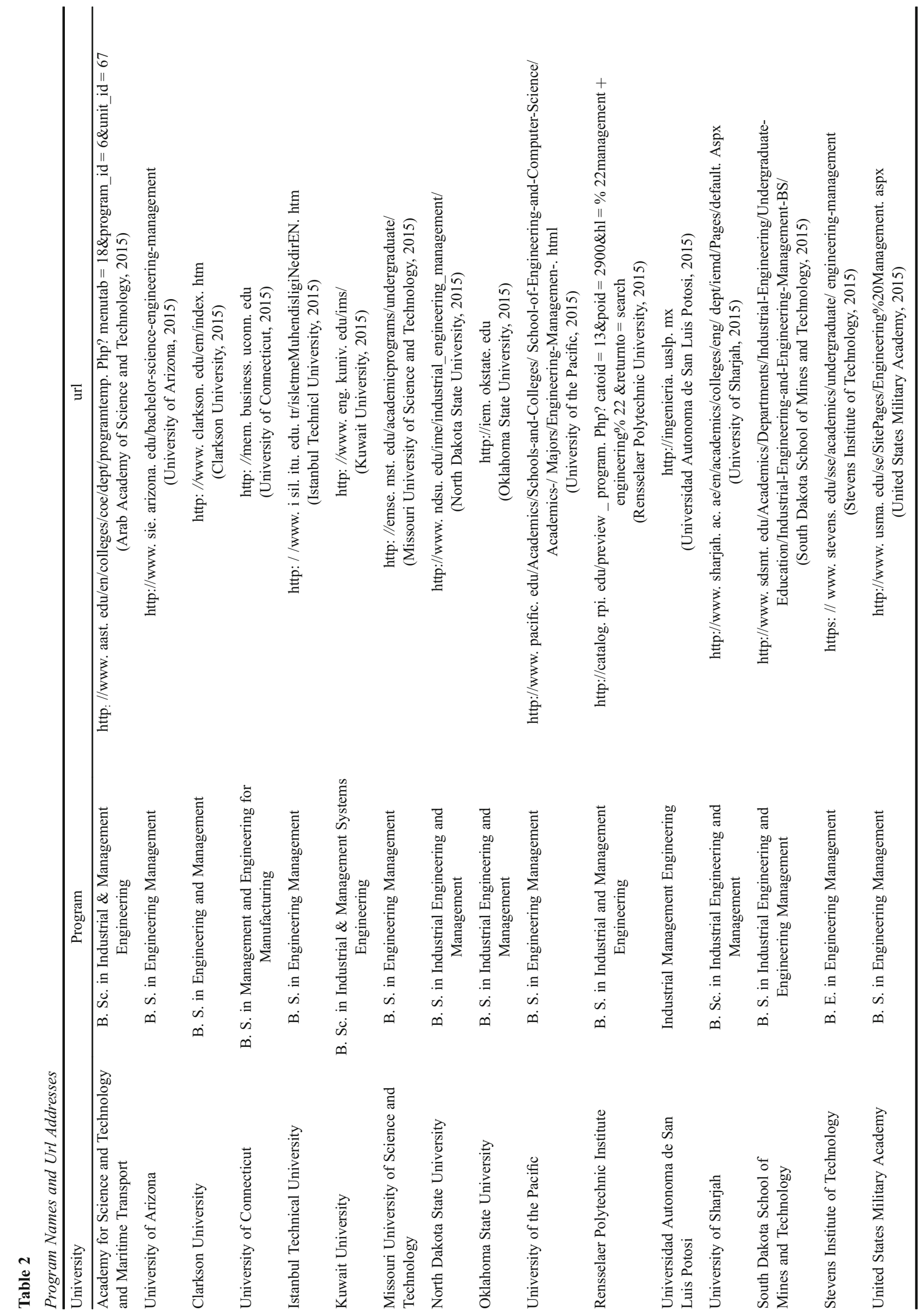


that students should first major in a traditional field before moving into engineering management. Many universities outside the US are more willing to establish degree programs that reflect newer or more specialized disciplines. It is also possible that outside the US there is a philosophy of developing engineers who can first work on teams and be effective in business settings, and then specialize in a technical field that is appropriate to their career.

With respect to preparing students to work effectively in a global setting, it does not appear that there is a consistent approach or methodology. It can be inferred that programs rely on the general education component to provide this, or that individual instructors may introduce ideas into individual courses. It appears that, from American universities at least, there is more interest in providing students with the opportunity to have an international experience as part of their programs.

In research that focused on the coverage of managerial topics in engineering management curricula, the authors surveyed a subset of the ABET-accredited programs that had undergone a recent submission of self-study materials or visits. That paper found that managerial topics are not consist-ently credited as engineering topics, even though they are included in the program-specific criteria for engineering management programs. Particular issues included whether particular courses were housed in either an engineering college or business college, if the courses were oriented toward engineering management or business, and the qualifications and perspective of the individual faculty instructor (ABET, Inc., 2015e). Readers who are interested in the literature over the past 20 years that is related to engineering management program content, assessment, and curricular design are referred to that paper.

\section{Summary, conclusions, and recommendations}

This paper has considered the ABET approach to accrediting engineering management programs, identified those programs, and investigated how they cover global issues and prepare their students to work in an international setting. This research focused solely on publicly available information from ABET and the 16 undergraduate programs by ABET's Engineering Accreditation Commission.

This work indicates that there is not a consistent intentional approach to covering global issues and preparing students to work in an international context. Clarkson University will require their engineering management students to have an international experience beginning in 2017. Further work should pursue data through surveys and interviews to better gauge the level and types of experiences students have in EM programs.

Undergraduate programs in engineering management prepare students to be extremely effective at managing projects, processes, and relationships within and between enterprises. As the world becomes increasingly interconnected, EM students in particular need to be exposed to experiences and opportunities that provide them with global context and the skills to work effectively in international settings.

From this work, several key conclusions and recommendations can be made. Engineering management is becoming a globally accepted engineering discipline for undergraduate majors. The number of ABET-accredited engineering management programs outside the United States can conceivably be greater than the number inside the US in the foreseeable future. ABET criteria for the accreditation of engineering management programs should consider the global aspect and international setting of future engineering managers, in addition to other topical areas of the discipline's body of knowledge and how to consistently classify courses covering managerial topics within the required curriculum. Although the Engineering Management Body of Knowledge of the American Society for Engineering Management (ASEM) (Shah, 2012) has not been discussed in this paper, it should be noted that future editions will evolve to incorporate the global aspects and international setting of the profession.

This is an exciting time for the engineering management profession, it is important for the programs to develop a consistent approach to help build a globally relevant and recognized curriculum. International collaboration and partnerships will play an integral role in designing the curriculum for the future.

\section{References}

ABET, Inc. (2015a). ABET history. Retrieved from http://www. abet. org/ History/

ABET, Inc. (2015b). ABET home. Retreieved from http: //www. abet. org

ABET, Inc. (2015c). ABET governance. Retrieved from http://www. abet. org/governance/

ABET, Inc. (2015d). Engineering program criteria for 2015-2016. Retrieved from http: //www. abet. org/eac-criteria-2015-2016/

ABET, Inc. (2015e). Accredited program search. Retrieved from http: // main. abet. org/aps/Accredited-programsearch.aspx

Arab Academy of Science and Technology. (2015). AAST industrial \& management engineering home. Retrieved from http://www. aast. edu/en/colleges/coe/dept/programtemp. Php? menutab $=18 \&$ progra$\mathrm{m} \_\mathrm{id}=6 \&$ unit_id $=67$

Clarkson University. (2015). Engineering \& management (E\&M). Retrieved from http://www. clarkson. edu/em/index. html

Istanbul Technical University. (2015). ITU faculty of management $>$ About management engineering. Retrieved from http://www. Isl. itu. edu. tr/isletmeMu- hendisligiNedirEN. htm

Kauffmann, P.J., Farr, J.V., Schott, E.W., \& Wyrick, D.A. (2015). An analysis of engineering credits in ABET accredited engineering 
management programs. Proceedings of the 2015 ASEE Annual Conference \& Exposition, Paper \# 13509, 1-14

Kuwait University. (2015). Industrial and management systems engineering department. Retrieved from http://www. eng. kuniv. edu/ims/

Missouri University of Science and Technology. (2015). Missouri S\&T$B S$ - engineering management. Retrieved from http://emse. mst. edu/ academicprograms/undergraduate/

North Dakota State University. (2015). Industrial engineering \& management- IME (NDSU). Retrieved from http://www. ndsu. edu/ ime/industrial_engineering_management/

Oklahoma State University. (2015). Industrial engineering \& management. Retrieved from http: //iem. okstate. edu

Rensselaer Polytechnic University. (2015) . Program: industrial and management engineering- Rensselaer Polytechnic Institute- Acolog ACMS. Retrieved from http://catalog. rpi. edu/preview_program. Php c catoid $=13 \&$ poid $=2900 \& \mathrm{hl}=\% 22$ management + engineering $\% 22 \&$ returnto $=$ search

Shah, H., ed. (2012). The Guide to the Engineering Management Body of Knowledge, 3rd Edition. Huntsville: American Society for Engineering Management

South Dakota School of Mines and Technology. (2015). Program: industrial engineering and engineering management. B. S. - South Dakota School of Mines \& Technology-Acolog ACMS. Retrieved from http://www. sdsmt. edu/Academics/Departments/IndustrialEngineering/Undergraduate-Education/Industriall-Engineering-and-
Engineering-Management-BS/

Stevens Institute of Technology. (2015). Undergraduate: engineering management / SSE-School of Systems \& Enterprise. Retrieved from https: //www. stevens. edu/sse/academics/undergraduate/engineeringmanagement

United States Military Academy. (2015). Department of systems engineering- engineering management. Retrieved from http://www. usma. edu/se/SitePages/ Engineering\%20Management. Aspx

University of Sharjah. (2015). Home. Retrieved from http:// www. sharjah. ac. ae/en/academics/colleges/eng/dept/iemd/Pages/default, aspx

Universidad Autonoma de San Luis Potosi. (2015). Principal. Retrieved from http://ingenieria. uaslp. $\mathrm{mx}$

University of Arizona. (2015). Bachelor of science in engineering management. Retrieved from http://www. Sic. arizona. edu/bachelorscience-engineering-management

University of Connecticut. (2015). Academics / management \& engineering for manufacturing. Retrieved from http: //mem. business, uconn. edu

University of the Pacific. (2015). Engineering management. Retrieved from http://www. pacific, edu/Academics/ Schools-and-Colleges/ School-of-Engineering- and-Computer-Science/Academics-/Majors/ Engineering-Management-Html

University of Sharjah. (2015). Home. Retrieved from http:// www. sharjah. ac. ae/en/academics/colleges/eng/dept/iemd/Pages/default. $\operatorname{aspx}$ 